\title{
The Fatty Acid Composition of Butter Stored in Sheep's or Goat's Stomach (Karinyagi)
}

\author{
Ilhan Gun ${ }^{*}$, Bedia Simsek ${ }^{2}$ \\ ${ }^{1}$ Department of Food Processing, Dairy Products Programme, Vocational School, Mehmet Akif Ersoy University, Burdur, Turkey; \\ ${ }^{2}$ Faculty of Engineering, Food Engineering Department, Süleyman Demirel University, Isparta, Turkey. \\ Email: *igun@mehmetakif.edu.tr
}

Received January $28^{\text {th }}, 2011$; revised April $15^{\text {th }}, 2011$; accepted April $23^{\text {rd }}, 2011$.

\begin{abstract}
Butter is produced from cream or yoghurt in dairy factories and farms and called as butter or yayik butter in Turkey. Karinyagi is also made from cream and yoghurt as yayik butter, but the packaging material is different from others. Karinyagi is produced by filling of butter into purified goat's and sheep's stomach (the traditional name is Karin) and storage in this material during self-life. The aim of this study was to determine the fatty acid composition of Karinyagi made from cream. Twenty Karinyagi samples were randomly collected from different regions of Burdur, Turkey. The fatty acid composition of samples (by gas chromatography) and chemical properties were investigated. It was determined that the chemical properties of Karinyagi were similar to butter produced with cream and yoghurt. The total saturated fatty acid level of Karinyagi samples changed from $62.31 \%$ to $76.64 \%$ (mean value $67.14 \pm 3.36 \%$ ), while unsaturated fatty acids of them ranged from $20.48 \%$ to $31.57 \%$ (mean value $28.46 \pm 2.67 \%$ ). Minimum and maximum levels of monounsaturated fatty acids of Karinyagi were determined as $18.98 \%$ and $28.57 \%$. Butyric, oleic and palmitic acids were dominant in Karinyagi. Palmitic acid was slightly lower comparing to data for butter produced with cream and yoghurt. As a result, the amount of Karinyagi fatty acids may be said to be significantly different from the fatty acid of yayik and cream butter.
\end{abstract}

Keywords: Karinyagi, Butter, Fatty Acid Compositions

\section{Introduction}

Due to cultural differences, producer's and customer's habits as well as applied technologies, butter making processes and its consumption levels are quite different in many countries. Extensively, sweet cream without salt is used in butter production. In addition, it can also be produced from cream acidulated or soured in a bacteriological way [1]. In Turkey, butter is produced from cream or yoghurt in dairy factories and farms. Yayik butter (churn butter) can be made both from fresh yoghurt or yoghurt stored in goat's skin bag (Tulum yoghurt) [2].

Industrial butter is packed with aluminum foil, plastic or paper wrap and stored, whereas Karinyagi is stored into a goat's or sheep's stomach (Karin) as a traditional way in The Mediterranean Region of Turkey $[3,4]$. The usage of the stomach of goat and sheep which allows air and water vapor permeability, in the storage of dairy products such as butter and cheese, is one of the oldest traditional storage methods [5-7]. Goat's or sheep's stomach is ef- fective in a positive way on characteristic properties of butters. There isn't any research reported on the effects of storage in Karin.

The goat's and sheep's stomach used in the production of Karinyagi was cleaned from the rough dirt and washed using $1 \% \mathrm{NaOH}$ and than rinsed with plenty of water, and finally salted. Stomachs were hanged and dried about one or two weeks. Karin was dampened before being used as butter packaging material.

The first step in cream butter production is cream pasteurization at $90^{\circ} \mathrm{C}-95^{\circ} \mathrm{C}$ for $15-20 \mathrm{~min}$ followed by cooling to $15^{\circ} \mathrm{C}-20^{\circ} \mathrm{C}$. After that, cream is churned for about 60 to $70 \mathrm{~min}$ until the fat globules coalesce. Buttermilk is removed and butter is washed once or twice. After washing, butter packages are foiled or wrapped in plastic material. In Karinyagi production, all stages are almost the same. According to the consumer's preference, salt is added to butter and whole material is pressed into the sheep's or goat's stomach. The filling of butter should be done carefully to prevent microbiological contamination and oxidation at this stage. Although 
several articles pertaining to the chemical composition of butter have been published, there is not any article about fatty acid composition of Karinyagi-the butter produced in a traditional way [8,9].

Karin used as packaging material for butter protection probably affects chemical properties of the product, including fatty acid composition. Furthermore, Karin may be also contaminated with microorganisms from the environment or the air may come into contact with the product due to Karin permeability. In result this may increase the rate of butter hydrolysis. Therefore, the aim of this study was to determine the fatty acid composition of Karinyagi stored in goat's or sheep's stomach and to compare it with cream and yayik butter's compositions.

\section{Materials and Methods}

\subsection{Materials}

Twenty Karinyagi samples were randomly collected from different regions of Burdur/Turkey. $250 \mathrm{~g}$ of the samples were placed in sterile jars and examined chemically. Samples were kept at $4^{\circ} \mathrm{C} \pm 1{ }^{\circ} \mathrm{C}$ during analysis.

\subsection{Methods}

\subsubsection{Physicochemical Analyses}

Titratable acidity (lactic acid \%) and moisture of butter was found by methods of James [10]. The contents of fat (\%) and non-fat solid of butter were measured according to A.O.A.C methods [11]. The $\mathrm{pH}$ value of samples was measured with a HANNA pH meter (HANNA Instruments, Italy). Each of 20 samples was analyzed in triplicate.

\subsubsection{Fatty Acid Analyses}

Fatty acid composition was determined using a modified fatty acid methyl ester method as described by Marquard [12]. The oil was extracted from $10 \mathrm{~g}$ sample by homogenisation with hexane. The reactive was from 500 $\mathrm{ml}$ of total Na-metaoxid $(0.5 \mathrm{~g})$, isooctane $(20 \mathrm{ml})$ and methanol $(80 \mathrm{ml})$ added to the oil $(50 \mu \mathrm{l})$. After the sample was kept one night, Isooctane $(500 \mu \mathrm{l})$ added to it. The methyl esters of the fatty acids $(0.5 \mathrm{ml})$ were analyzed in a Hewlett-Packard 6890 series gas chromatograph (Perkin Elmer Auto System XL., USA) equipped with a flame ionizing detector (FID), a fused silica capillary column $(\mathrm{MN}$ FFAP $(50 \mathrm{~m} \times 0.32 \mathrm{~mm}$ i.d.); film thickness $0.2 \mu \mathrm{m}$ ). It was operated under the following conditions: oven temperature program, $120^{\circ} \mathrm{C}$ for $1 \mathrm{~min}$. raised to $240^{\circ} \mathrm{C}$ at a rate of $6^{\circ} \mathrm{C} / \mathrm{min}$ and than kept at $240^{\circ} \mathrm{C}$ for $15 \mathrm{~min}$; injector and detector temperatures; $250^{\circ} \mathrm{C}$ and $260^{\circ} \mathrm{C}$ respectively; carrier gas, helium at flow rate of $40 \mathrm{ml} / \mathrm{min}$; split ratio. $1 / 20 \mathrm{ml} / \mathrm{min}$. The contents of palmitic $\left(\mathrm{C}_{16: 0}\right)$, stearic $\left(\mathrm{C}_{18: 0}\right)$, oleic $\left(\mathrm{C}_{18: 1}\right)$, linoleic $\left(\mathrm{C}_{18: 2}\right)$ and linolenic $\left(\mathrm{C}_{18: 3}\right)$ acids were determined by computing integrator.

\subsubsection{Statistical Analysis}

All statistical analysis was performed via SPSS 15.0 for Windows.

\section{Results and Discussion}

Minimum, maximum (and mean \pm SD) values of total solid, fat, moisture, $\mathrm{pH}$, salt in samples were found as $82.15 \%-87.86 \%(84.15 \% \pm 1.30 \%), 80 \%-85 \%$ $(82.08 \% \pm 1.31 \%), 12.14 \%-17.85 \%(16.22 \% \pm 1.05 \%)$, $3.7 \%-5.47 \%(4.51 \% \pm 0.46 \%), 0.28 \%-2.18 \%(1.08 \%$ $\pm 0.64 \%$ ), respecttively. It was determined that these values were not ex- ceeding the limit value of Turkish Food Codex [13]. A similar result has also been reported in Karinyagi sam- ples by Gün [4]. We have obtained for Karinyagi com- pared with other researcher's findings on cream and yayik butter [14]. It was found that while the moisture ratio of Karinyagi were low, its fat content were higher than cream and yayik butter samples.

The fatty acid composition of Karinyagi was gathered in Table 1. Obtained results demonstrate that total saturated fatty acid level changed from $62.31 \%$ to $76.64 \%$ (mean value $67.14 \pm 3.36 \%$ ), while total unsaturated fatty acids ranged from $20.48 \%$ to $31.57 \%$ (mean value 28.46 $\pm 2.67 \%$ ). The most common saturated fatty acids occurring in milk fat are palmitic and stearic acid. Both of the fatty acids are important for human energy metabolism and normal growth [15]. The data concerning mean values of saturated and unsaturated fatty acid were presented in Figures 1 and 2. Furthermore, fatty acid compositions of different type butter produced in Turkey are shown in Table 2. Saturated fatty acids in milk fat mainly consist of three acids (palmitic: $28.75 \%$, stearic:

Table 1. Fatty acid composition of different type butter.

\begin{tabular}{llll}
\hline Free fatty acid & Karinyagi & $\begin{array}{l}\text { Cream } \\
\text { butter }^{*}\end{array}$ & $\begin{array}{l}\text { Yayik } \\
\text { butter }^{* *}\end{array}$ \\
\hline Butyric acid $\left(\mathrm{C}_{4: 0}\right)$ & 3.23 & 2.395 & 1.83 \\
Caproic acid $\left(\mathrm{C}_{6: 0}\right)$ & 1.63 & 1.75 & 1.18 \\
Caprylic acid $\left(\mathrm{C}_{8: 0}\right)$ & 0.98 & 1.12 & 0.81 \\
Capric acid $\left(\mathrm{C}_{10: 0}\right)$ & 2.39 & 2.59 & 1.97 \\
Lauric acid $\left(\mathrm{C}_{12: 0}\right)$ & 2.85 & 3.15 & 2.4 \\
Myristic acid $\left(\mathrm{C}_{14: 0}\right)$ & 10.65 & 11.45 & 11.17 \\
Palmitic acid $\left(\mathrm{C}_{16: 0}\right)$ & 32.68 & 34.60 & 33.72 \\
Margaric acid $\left(\mathrm{C}_{17: 0}\right)$ & 0.60 & 0.13 & 1.07 \\
Stearic acid $\left(\mathrm{C}_{18: 0}\right)$ & 12.12 & 12.16 & 10.47 \\
Undecanoic acid $\left(\mathrm{C}_{11: 1}\right)$ & 0.19 & $\mathrm{NA}{ }^{* * *}$ & NA \\
Palmitoleic acid $\left(\mathrm{C}_{16: 1}\right)$ & 0.98 & 0.66 & 0.81 \\
Heptadecanoic acid $\left(\mathrm{C}_{17: 1}\right)$ & 0.36 & 0.38 & NA \\
Oleic acid $($ trans $)\left(\mathrm{C}_{18: 1}\right)$ & 1.43 & 0.003 & ND ${ }^{* * *}$ \\
Oleic acid $($ cis $)\left(\mathrm{C}_{18: 1}\right)$ & 22.68 & NA & 21.78 \\
Linoleic acid $\left(\mathrm{C}_{18: 2}\right)$ & 2.22 & NA & NA \\
Linolenic acid $\left(\mathrm{C}_{18: 3}\right)$ & 0.58 & NA & NA \\
\hline${ }^{*}$ Seçkin et al. $[2] ;{ }^{* *}$ Sağdiç et al. $[1] ;{ }^{* * *}$ Not Analyzed; ${ }^{* * * *}$ Not Detected.
\end{tabular}




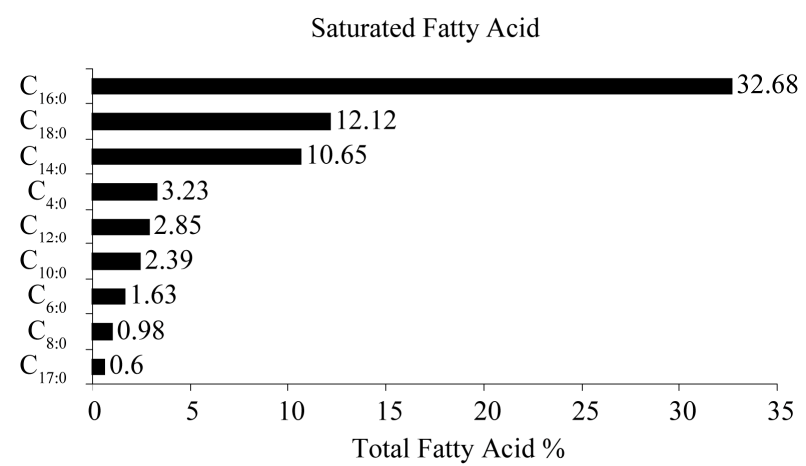

Figure 1. Saturated fatty acids of Karinyagi (\%).

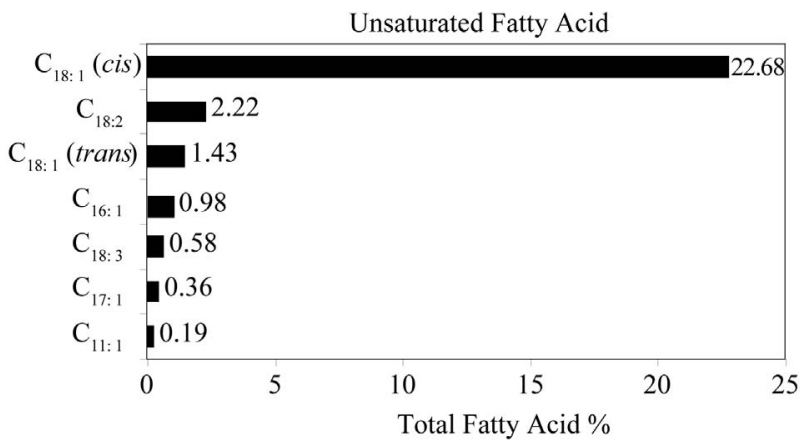

Figure 2. Unsaturated fatty acids of Karinyagi (\%).

9.44\%, myristic: $11.35 \%)$ [16]. Palmitic $\left(\mathrm{C}_{16: 0}: 32.68 \pm\right.$ $1.88 \%)$, stearic $\left(\mathrm{C}_{18: 0}: 12.12 \% \pm 1.59 \%\right)$ and myristic acid $\left(\mathrm{C}_{14: 0}: 10.65 \% \pm 1.36 \%\right)$ was found the highest level in saturated fatty acid of Karinyagi samples. Palmitic acid is one of the saturated fatty acids causing raise of serum cholesterol while stearic acid does not influence serum cholesterol [17]. Therefore, from nutritional point of view it is an unwanted component. Unfortunately, palmitic acid was the highest level out of all saturated fatty acid occurring in Karinyagi samples. This level is slightly lower comparing to data for butter produced with cream and yoghurt. Seçkin et al. [2] reported that palmitic acid content of butter was $34.6 \%$. Stearic and myristic acid contents were $12.16 \%$ and $11.45 \%$ respecttively.

Butyric acid is the most widely known saturated fatty acid and is responsible for rancidity of butter lipolysis. Actually, butyric acid has a potent inhibitor of cancer cell proliferation and butter is one of the sources for diet [18]. Butyric acid $\left(\mathrm{C}_{4: 0}\right)$ content of Karinyagi was determined as $3.23 \% \pm 1.38 \%$. This value was found as $1.83 \%$ in the butter obtained from cow's milk fat [1]. Butyric acid content of Karinyagi is two times higher than yayik butter and this value is important for consumer health.

Other important components of butter are capric $\left(\mathrm{C}_{10: 0}\right)$, caproic $\left(\mathrm{C}_{6: 0}\right)$ and caprylic acids $\left(\mathrm{C}_{8: 0}\right)$. These acids were considered to be responsible for taste disor- ders such as sharp pepper (nipping) and soapy. The level of capric acid $(2.39 \% \pm 0.82 \%)$ is significantly higher than level of caproic acid $(1.63 \% \pm 0.68 \%)$ and caprylic acid $(0.98 \pm 0.38 \%)$ in Karinyagi (Figure 1). In contrast, Capric, caproic and caprylic acid content of yayik butter (butter produced traditional way) were determined as $1.97 \%, 1.18 \%$ and $0.81 \%$ respectively [1]. Additionally, the level of undecanoic $\left(\mathrm{C}_{11: 1}\right)(0.19 \% \pm 0.08 \%)$, heptadecanoic $\left(\mathrm{C}_{17: 1}\right)(0.36 \% \pm 0.19 \%)$ and palmitoleic $\left(\mathrm{C}_{16: 1}\right)$ $(0.98 \pm 0.33 \%)$ acids in studied samples were lower than the result of comparison of Karinyagi and cream butter. it was found that level of heptadecanoic acid in cream butter $(0.38 \%)$ was similar to Karinyagi while level of palmitoleic acid was significantly higher $(0.66 \%)$ than Karinyagi [2].

The total unsaturated fatty acids are classified in two groups; monounsaturated (MUFA) and polyunsaturated (PUFA) (Table 1). The monounsaturated fatty acids level was ranged from $18.98 \%$ to $28.57 \%$ (mean value $25.65 \% \pm 2.48 \%$ ). Sağdıç et al. [1] analyzed saturated and unsaturated fatty acid composition of Turkish yayik butter obtained from goats', ewes' and cows' milk. The unsaturated fatty acid average values were determined as $22.35 \%, 23.18 \%$ and $25.34 \%$ for goat, ewe and cow's yayik butter [1].

Oleic acid $\left(\mathrm{C}_{18: 1}(\mathrm{cis})\right)$ content of Karinyagi was the highest $(22.68 \% \pm 2.16 \%)$ of all the monounsaturated fatty acids (Figure 2). Although cis form of monounsaturated fatty acid was the highest, the level of trans fatty acid was very low in Karinyagi samples. At a research on yayik butter made from cow's milk, $\mathrm{C}_{18: 1}$ (cis) was $21.78 \%$ while $\mathrm{C}_{18: 1}$ (trans) form was not detected. But $\mathrm{C}_{18: 1}$ (trans) form was $1.43 \% \pm 0.39 \%$ in Karinyagi. This value was also higher than cream butter $(0.003 \%)$ [2]. The polyunsaturated fatty acid is required for human. Unfortunately, humans do not have the enzymatic capacity to synthesize the PUFA, so that it must be provided with the diet [19]. Linoleic and linolenic acids are nutritionally essential fatty acids, it is important to provide them with diet. The polyunsaturated fatty acid in Karinyagi was found between 1.50 and $4.40 \%$ (mean value $2.81 \% \pm 0.59 \%$ ). It was found that the linoleic acid $\left(\mathrm{C}_{18: 2}\right)$ was higher $(2.23 \% \pm 0.56 \%)$ than the lino-lenic acid $\left(\mathrm{C}_{18: 3}\right)(0.58 \% \pm 0.18 \%)$ in Karinyagi. Diraman [20] was indicated that linoleic and linolenic fatty acid in cream butter were $2.14 \%$ and $0.27 \%$ respecttively. According to these results, linoleic acid level in Karinyagi is two times higher than in cream butter.

\section{Conclusions}

In this study, the fatty acid profiles of Karinyagi were investigated and categorized. Butyric acid level of Karinyagi butter was higher than yayik and cream butter. 
Table 2. The fatty acid composition of Karinyagi.

\begin{tabular}{|c|c|c|c|c|c|c|c|c|c|c|c|c|c|c|c|c|c|c|c|c|c|}
\hline \multirow{2}{*}{$\begin{array}{l}\text { Free } \\
\text { fatty } \\
\text { acids }\end{array}$} & \multicolumn{21}{|c|}{ Karinyagi Samples } \\
\hline & 1 & 2 & 3 & 4 & 5 & 6 & 7 & 8 & 9 & 10 & 11 & 12 & 13 & 14 & 15 & 16 & 17 & 18 & 19 & 20 & $\begin{array}{c}\text { Mean } \\
\pm \text { SD }\end{array}$ \\
\hline SFA & 69.53 & 63.79 & 64.36 & 66.09 & 66.91 & 68.41 & 64.26 & 68.47 & 69.71 & 71.87 & 76.64 & 66.14 & 69.6 & 66.75 & 64.72 & 68.87 & 63.85 & 64.49 & 966.09 & 62.31 & $\begin{array}{l}67.14 \\
\pm 3.36\end{array}$ \\
\hline $\mathrm{C}_{4: 0}$ & 5.03 & 3.52 & 1.70 & 3.34 & 3.45 & 3.39 & 2.68 & 3.81 & 6.28 & 5.13 & 5.82 & 2.13 & 2.32 & 2.20 & 2.01 & 2.29 & 1.88 & 2.69 & 1.63 & 3.37 & $\begin{array}{l}3.23 \\
\pm 1.38\end{array}$ \\
\hline$C_{6: 0}$ & 2.52 & 1.70 & 0.80 & 1.69 & 1.65 & 1.74 & 1.27 & 1.95 & 2.91 & 2.64 & 3.04 & 1.12 & 1.16 & 1.02 & 1.05 & 1.21 & 1.00 & 1.28 & 0.94 & 1.96 & $\begin{array}{l}1.63 \\
\pm 0.68\end{array}$ \\
\hline $\mathrm{C}_{8: 0}$ & 1.49 & 0.96 & 0.52 & 1.00 & 1.05 & 1.07 & 0.73 & 1.17 & 1.57 & 1.56 & 1.87 & 0.67 & 0.71 & 0.61 & 0.66 & 0.81 & 0.70 & 0.76 & 0.60 & 1.10 & $\begin{array}{l}0.98 \\
\pm 0.38\end{array}$ \\
\hline$C_{10: 0}$ & 3.26 & 2.11 & 1.58 & 2.40 & 2.54 & 2.58 & 1.64 & 2.85 & 3.32 & 3.59 & 4.79 & 1.61 & 2.03 & 1.66 & 1.73 & 2.15 & 2.04 & 2.03 & 1.63 & 2.30 & $\begin{array}{l}2.39 \\
\pm 0.82\end{array}$ \\
\hline$C_{12: 0}$ & 3.40 & 2.32 & 2.37 & 2.63 & 3.26 & 2.87 & 2.22 & 3.14 & 3.14 & 3.88 & 5.21 & 2.08 & 2.84 & 2.36 & 2.48 & 2.83 & 2.72 & 2.44 & 2.47 & 2.37 & $\begin{array}{l}2.85 \\
\pm 0.72\end{array}$ \\
\hline $\mathrm{C}_{14: 0}$ & 11.17 & 9.44 & 10.27 & 9.84 & 9.95 & 10.36 & 9.70 & 10.84 & 9.90 & 12.25 & 15.20 & 9.67 & 11.56 & 10.43 & 10.55 & 11.81 & 10.61 & 10.00 & 10.74 & 8.72 & $\begin{array}{l}10.65 \\
\pm 1.36\end{array}$ \\
\hline$C_{16: 0}$ & 31.42 & 30.43 & 32.96 & 32.00 & 35.41 & 32.55 & 32.72 & 31.16 & 29.96 & 31.03 & 33.15 & 34.53 & 35.43 & 34.50 & 32.96 & 36.10 & 32.18 & 31.79 & 934.01 & 29.32 & $\begin{array}{l}32.68 \\
\pm 1.88\end{array}$ \\
\hline $\mathrm{C}_{17: 0}$ & 0.11 & 0.20 & 0.83 & 0.30 & 0.30 & 0.41 & 0.83 & 0.25 & 0.70 & 0.68 & 0.54 & 0.95 & 0.96 & 0.70 & 0.74 & 0.61 & 0.70 & 0.57 & 0.95 & 0.75 & $\begin{array}{l}0.60 \\
\pm 0.26\end{array}$ \\
\hline$C_{18: 0}$ & 11.13 & 13.11 & 13.33 & 12.89 & 9.30 & 13.44 & 12.47 & 13.30 & 11.93 & 11.11 & 7.02 & 13.38 & 12.59 & 13.27 & 12.54 & 11.06 & 12.02 & 12.93 & 313.12 & 12.42 & $\begin{array}{l}12.12 \\
\pm 1.59\end{array}$ \\
\hline TUFA & 26.97 & 30.05 & 29.84 & 29.38 & 25.50 & 28.08 & 31.10 & 27.97 & 27.98 & 24.97 & 20.48 & 31.57 & 27.65 & 27.11 & 29.90 & 27.76 & 30.28 & 31.07 & 730.67 & 30.87 & $\begin{array}{l}28.46 \\
\pm 2.67\end{array}$ \\
\hline MUFA & 24.28 & 27.20 & 27.06 & 26.63 & 21.10 & 25.38 & 28.24 & 25.48 & 25.43 & 22.65 & 18.98 & 28.57 & 24.86 & 24.45 & 27.24 & 25.25 & 27.43 & 26.92 & 27.97 & 27.91 & $\begin{array}{l}25.65 \\
\pm 2.48\end{array}$ \\
\hline $\mathrm{C}_{11: 1}$ & 0.26 & 0.20 & 0.12 & 0.24 & 0.14 & 0.24 & 0.18 & 0.24 & 0.10 & 0.32 & 0.40 & 0.14 & 0.18 & 0.13 & 0.15 & 0.16 & 0.18 & 0.11 & 0.12 & 0.23 & $\begin{array}{l}0.19 \\
\pm 0.08\end{array}$ \\
\hline$C_{16: 1}$ & 0.28 & 0.72 & 1.25 & 0.61 & 0.46 & 0.39 & 1.43 & 0.95 & 0.99 & 1.02 & 1.01 & 1.20 & 1.05 & 1.22 & 0.98 & 1.31 & 1.32 & 0.96 & 1.28 & 1.23 & $\begin{array}{l}0.98 \pm \\
0.33\end{array}$ \\
\hline$C_{17: 1}$ & 0.85 & 0.25 & 0.27 & 0.32 & 0.20 & 0.22 & 0.31 & 0.20 & 0.65 & 0.64 & 0.15 & 0.36 & 0.43 & 0.17 & 0.20 & 0.22 & 0.29 & 0.48 & 0.49 & 0.48 & $\begin{array}{l}0.36 \pm \\
0.19\end{array}$ \\
\hline $\begin{array}{l}\mathrm{C}_{18: 1} \\
\text { (trans) }\end{array}$ & 1.64 & 1.31 & 1.94 & 1.28 & 1.20 & 1.68 & 1.61 & 1.41 & 1.17 & 1.17 & 0.40 & 1.44 & 1.23 & 1.81 & 1.87 & 0.76 & 1.79 & 1.43 & 1.76 & 1.77 & $\begin{array}{l}1.43 \\
\pm 0.39\end{array}$ \\
\hline $\begin{array}{l}\mathrm{C}_{18: 1} \\
\text { (cis) }\end{array}$ & 21.25 & 24.72 & 23.48 & 24.18 & 19.10 & 22.85 & 24.71 & 22.68 & 22.52 & 19.50 & 17.02 & 25.43 & 21.97 & 21.12 & 24.04 & 22.8 & 23.85 & 23.94 & 424.32 & 24.20 & $\begin{array}{l}22.68 \\
\pm 2.16\end{array}$ \\
\hline PUFA & 2.69 & 2.85 & 2.78 & 2.75 & 4.40 & 2.70 & 2.86 & 2.49 & 2.55 & 2.32 & 1.50 & 3.00 & 2.79 & 2.66 & 2.66 & 2.51 & 2.85 & 4.15 & 2.70 & 2.96 & $\begin{array}{l}2.81 \\
\pm 0.59\end{array}$ \\
\hline $\mathrm{C}_{18: 2}$ & 2.06 & 2.35 & 2.08 & 2.29 & 4.10 & 2.16 & 2.24 & 1.97 & 2.01 & 1.82 & 1.20 & 2.30 & 1.98 & 2.07 & 2.05 & 2.12 & 2.11 & 3.15 & 2.35 & 2.16 & $\begin{array}{l}2.23 \\
\pm 0.56\end{array}$ \\
\hline$C_{18: 3}$ & 0.63 & 0.50 & 0.70 & 0.46 & 0.30 & 0.54 & 0.62 & 0.52 & 0.54 & 0.50 & 0.30 & 0.70 & 0.81 & 0.59 & 0.61 & 0.39 & 0.74 & 1.00 & 0.35 & 0.80 & $\begin{array}{l}0.58 \\
\pm 0.18 \\
\end{array}$ \\
\hline
\end{tabular}

SFA: Saturated fatty acid. TUFA: Total Unsaturated fatty acid. MUFA: Monounsatureted fatty acid. PUFA: Polyunsaturated fatty acid, SD: Standard Deviation.

The fatty acid profile of butter preserved by pressed sheep's or goat's stomachs showed that oleic acid was predominant; in addition, palmitic acid was the major monounsaturated fatty acid. Stearic and myristic acids were also found as high quantities in Karinyagi. As a result, the amount of Karinyagi fatty acids can be said to be significantly different from the fatty acid of yayik and cream butter. We anticipate that these differences in packaging materials (goat's and sheep's bellies) may have causes. Therefore, it is needed more research on 
Karin properties as packaging material and its effect on butter.

\section{REFERENCES}

[1] O. Sağdıç, M. Dönmez and M. Demirci, "Comparison of Characteristics and Fatty Acid Profiles of Traditional Turkish Yayik Butters Produced from Goats', Ewes' or Cows' Milk," Food Control, Vol. 15, No. 6, 2004, pp. 485-490. doi:10.1016/i.foodcont.2003.07.003

[2] A. K. Seçkin, O. Gürsoy, Ö. Kınık and N. Akbulut, "Conju-Gated Linoleic Acid (CLA) Concentration, Fatty Acid Composition and Cholesterol Content of Some Turkish Dairy Products," Swiss Society of Food Science and Technology, Vol. 38, No. 8, 2005, pp. 909-915.

[3] İ. Gün, "Traditional Milk Product: Karinyagi," Recent Development in Dairy Science and Technology International Dairy Symposium Proceedings, Isparta, 2004, pp. 281-284.

[4] İ. Gün, "Burdur'da Üretilen Karınyağlarının Bazı Kalite Özellikleri ve Üretim Teknolojisi," SDÜ Fen Bilimleri Enstitüsü Dergisi, Vol. 7, No. 3, 2003, pp. 55-58.

[5] H. Ünsal, "Süt Uyuyunca-Türkiye Peynirleri," A Yapı Kredi Yayınları, Istanbul, 1997.

[6] B. Şimşek and İ. Gün, "Free Fatty Acid Composition of Akcakatik Cheese, a Traditional Turkish Dairy Product," Asian Journal of Chemistry, Vol. 21, No. 8, 2009, pp. 5923-5928.

[7] F. Durlu-Özkaya and İ. Gün, "Traditional Turkish Cheeses," International Symposium Historical Cheeses of Countiries Around the Archipelago Mediterraneo, Thessalaniki, 2007, pp. 65-88.

[8] B. Dashti, F. Al-Awadi, W. Sawaya, J. Al-Otaibi and A. Al-Sayegh, "Fatty Acid Profile and Cholesterol Content of 32 Selected Dishes in the State of Kuwait," Food Chemistry, Vol. 80, 2003, pp. 377-386.

[9] R. R. Grummer, "Effect of Feed on the Composition of
Milk Fat," Journal of Dairy Science, Vol. 74, No. 9, 1991, pp. 3244-3257.

[10] C. S. James, "Analytical Chemistry of Foods," Blackie Academic and Professional, London, 1995.

[11] Association of Official Analytical Chemists, "AOAC Official Methods of Analysis," 13th Edition, Washington, 1980.

[12] R. Marquard, "Qualitatsanalytik im Dienste Der OlpflanZenzuchtung." Fat Science Technology, Vol. 89, 1987, pp. 95- 99.

[13] Anonymous, “Tereyağı. Diğer Süt Yağı Esaslı Sürülebilir Ürünler ve Sadeyağ Tebliği," Resmi Gazete, Vol. 12, No. 25784, 2005, pp. 1-4.

[14] A. A. Hayaloglu and A. Konar, "A Comparative Study on Physicochemical and Sensorial Properties of Butter Made from Yogurt and Cream," Milchwissenchaft, Vol. 56, No. 12, 2001, pp. 675-677.

[15] P. Mason, "Fatty Acids: Which Ones do We Need?" The Pharmaceutical Journal, Vol. 273, 2004, pp. 750-752.

[16] M. Metin, "Süt Teknolojisi-Sütün Bileşimi ve İşlenmesi," Ege Üniversitesi Yayınları, Bornova/İzmir, 1996.

[17] S. M. Grundy, "What Is the Desirable Ratio of Saturated, Polyunsaturated and Monounsaturated Fatty Acids in the Diet?" American Journal of Clinical Nutrition, Vol. 66, No. 4, 1997, pp. 988-990..

[18] P. W. Parodi, "Cows' Milk Fat Components as Potential Anti-carcinogenic Agents," Journal of Nutrition, Vol. 127, No. 6, 1997, pp. 1055-1060.

[19] D. L. Nelson and M. M. Cox, "Principles of Biochemistry." 5th Edition, W. H. Freeman and Company, New York, 2008.

[20] H. Diraman, “İzmir İlinde Satılan Bazı Türk Süt Ürünlerindeki Yağ Asitlerinin Cis-Trans İzomerleri ve Konjuge Linoleik Asit Düzeylerinin Kapiler Gaz Kromatografik Yöntem İle Belirlenmesi Üzerine Bir Çalışma," Gida, Vol. 29, No. 5, 2004, pp. 381-389. 